\title{
The Consequences of Consumer Engagement in Social Networking Sites ${ }^{1}$
}

\begin{abstract}
Abubakar Lujja ${ }^{a}$
F. Zeynep Özata ${ }^{b}$

Abstract: Consumer Engagement is increasingly becoming one of the important issues in the competitive business environment and with its unique features and structure, Social Networking Sites offer an upper advantage to build consumer brand relationships and instant consumer engagement. This study set out to determine the consequences of consumer engagement in social networking sites. Consumer engagement was viewed as a multi-dimensional concept comprising behavioral, cognitive and emotional dimensions and as such the hypotheses were aimed at determining how each of the three dimensions of consumer engagement affect the individual consequences of consumer engagement such as brand loyalty, satisfaction, commitment and trust. The study used a quantitative research design. It used a questionnaire survey to collect data from university students. Facebook is chosen as a case for this study. 400 questionnaires were collected and the analyses were conducted with the 387 valid questionnaire. The results suggest that emotional and behavioral engagement dimensions were significant predictors for brand loyalty; emotional engagement for satisfaction, cognitive and behavioral engagement for commitment, while behavioral and emotional engagement dimensions were found to be significant predictors for trust.
\end{abstract}

Keywords: Consumer Engagement, Social Networking Sites, Loyalty, Trust, Satisfaction

JEL Classification: M31, L86

\section{Introduction}

Social networking is a phenomenon that has grown rapidly in the last decade (Xevelonakis, 2012:99), and as such Social Networking Sites (SNS) such as Facebook, Twitter, Linkedln, etc, have attracted tens of millions of users, many of whom have integrated these sites into their daily practices. These social media tools have globally influenced communications, interactions, and relationships for personal, business and organizational reasons. This has resulted in more and more brands to embrace the new media as another way to engage their consumers at a more or less personal level through virtual brand communities more especially SNS. Consumer engagement in SNS draws much attention of scholars and practitioners due to the fact that it facilitates a new way engaging with consumers through faster and spontaneous interactions between brands and consumers and also among consumers themselves (Ellison et al., 2007). SNS can therefore be used to create, sustain and develop new and existing relationships (Trusov et al., 2009). 
Consumer engagement as recent research topic (see Sashi, 2012:253; Malciute, 2012:1) has received considerable growing attention from among academicians, managers and practitioners. While recent academic and commercial studies have investigated the phenomenon of consumer engagement and social network sites (e.g. Marsden, 2010a), there is more need to conduct more research on consumer engagement in SNS. This is also supported by the calls for more research on the subject by the Marketing Science Institute (cited by Brodie, Bilijana Juric and Hollebeek, 2013; Malciute, 2012). This research attempts to fill existing knowledge gap in the literature by exploring consumer engagement in SNS.

Although there seem to be a general agreement on some consequences of consumer engagement for example on brand loyalty (Brodie et al., 2013; Malciute, 2012; Bowden, 2009; Casalo, Flavian and Guinaliu, 2007; Shang, Chen and Liao, 2006; Vivek, Beatty and Morgan, 2012; Wirtz et al., 2013), there is a sharp disagreement on some other considered consequences of consumer engagement. For example Malciute (2012) considered satisfaction as an antecedent of consumer engagement, while Sashi (2012) and Brodie et al., (2013) considered it to be an outcome of consumer engagement. Malciute (2012) considered commitment as an antecedent of consumer engagement while Vivek et al., (2012) and Sashi (2012) considered it as a consequence of consumer engagement. Therefore, this disagreement in such a new field of research has prompted the researcher to conduct a further study to try to exactly determine the consequences of consumer engagement.

The main objective of the study is to understand the consequences of consumer engagement among brands that maintain an online presence through social networking sites such as Facebook. Consumer engagement is a multi-dimensional construct. So this study views consumer engagement in terms of cognitive, emotional, and behavioral dimensions (Bowden 2009; van Doorn et al., 2010; Schaufeli et al., 2002:74). It further seeks to find out variables that are believed to be the consequences of the dimensions of consumer engagement In the literature, there are some seminal researches related to investigate the consequences of consumer engagement. Brand loyalty, satisfaction, commitment and trust are mostly aforementioned outcomes of consumer engagement. So this study intends to explore if cognitive, emotional and behavioral engagement in SNS affect brand loyalty, brand satisfaction, brand commitment and trust on brand.

This study aims to broaden past study findings on consumer engagement and its consequences. In most studies conducted in the area of consumer engagement, both antecedents and consequences are considered. On the other hand, most studies consider engagement as a uni-dimensional construct. This study aims to broaden the theory by considering consumer engagement as a multi-dimension construct and also testing the effects of each dimension on the consequences of engagement. Findings will be able to show which dimension of consumer engagement is more effective on the consequences, which dimension should be considered more seriously to increase brand loyalty, satisfaction, commitment and trust (Cheung et al., 2011; Zheng et al., 2015; van Doorn et al., 2010; Bijmolt et al., 2010; Bowden et al., 2009; Patterson et al., 2006; Gummerus et al., 2012; Wirtz et al., 2013). The Marketers and sales executives will also use the findings to improve their qualities of modernizing marketing and communication towards consumers and prospects. By this way, the marketing managers will be able to focus on the right engagement dimension related to their social media campaign objectives.

\section{Consumer Engagement}

One of the early definitions of engagement within brand communities refers to it as consumer's intrinsic motivation to interact and cooperate with community members (Algesheimer et al., 2005). Vivek (2009) defined consumer engagement as the intensity of consumer's participation and connection with the organization's offerings, and or organized activities. Doorn et al., (2010) defined it as customer's behavioral manifestations that have a brand or firm focus, beyond purchase, resulting from motivational drivers. Engagement may also be used as a measurement of the strength of a company or brand - customer relationships (McEwen, 2004). Engagement is therefore argued to include feelings of confidence, integrity, pride, and passion in a brand (McEwen, 2004). 
Customer engagement can be defined with different views. These are some examples, which see customer engagement as a process, as a behavioral manifestation or as a psychological state.

- Consumer engagement as a process: Bowden (2009) postulated customer engagement as a psychological process that leads to the formation of loyalty.

- Consumer engagement as behavioral manifestation: Van Doorn et al., (2010:254) defined customer engagement as "the behavioral manifestation from a customer toward a brand or a firm which goes beyond purchase behavior".

- Consumer engagement as psychological state: Patterson et al., (2006) drew on a variety of parent disciplines including social psychology and organizational behavior and defined customer engagement as a psychological state that is characterized by a degree of vigor, dedication, absorption, and interaction.

Brodie et al., (2013:107) defined consumer engagement as involving specific interactive experiences between consumers and the brand, and/ or other members of the community. The Table 1 below shows selected definitions of consumer engagement and consumer brand engagement from different authors.

Table 1. Selected Definitions of Consumer Engagement and Consumer Brand Engagement

\begin{tabular}{|c|c|}
\hline Reference & Definition \\
\hline $\begin{array}{l}\text { Vivek, Beatry and Mogan } \\
\text { (2012: 133) }\end{array}$ & $\begin{array}{l}\text { Consumer Engagement is the intensity of an individual's participation } \\
\text { in and connection with an organization's offerings and or organizational } \\
\text { activities, which either the customer or the organization initiate. }\end{array}$ \\
\hline Brodie et al., (2011b:260) & $\begin{array}{l}\text { Consumer Engagement a psychological state that occurs by virtue of } \\
\text { interactive, co-creative customer experience with a focal agent/object } \\
\text { (e.g a brand) in focal service relationships }\end{array}$ \\
\hline Hollebeek (2011:790) & $\begin{array}{l}\text { Customer Brand Engagement refers to the level of a customer's } \\
\text { motivational, brand-related and context dependent state of mind } \\
\text { characterized by specific levels of cognitive, emotional, and behavioral } \\
\text { activity in brand interactions. }\end{array}$ \\
\hline Patterson et al., (2006a) & $\begin{array}{l}\text { Consumer Engagement is the level of a customer's physical, cognitive } \\
\text { and emotional presence in their relationship with a service } \\
\text { organization. }\end{array}$ \\
\hline Van Doorn et al. (2010:254) & $\begin{array}{l}\text { Customer Engagement refers to the behavioral manifestation from a } \\
\text { customer toward a brand or a firm, which goes beyond purchase } \\
\text { behavior. }\end{array}$ \\
\hline Forester Consulting (2008) & $\begin{array}{l}\text { Consumer Engagement refers to creating deep connections with } \\
\text { customers that drive purchase decisions, interaction, and in } \\
\text { participation over time. }\end{array}$ \\
\hline $\begin{array}{l}\text { Marketing Science Institute } \\
(2010: 4)\end{array}$ & $\begin{array}{l}\text { Consumer Engagement refers to customers' behavioral manifestation } \\
\text { towards a brand or a firm beyond purchase, which results from } \\
\text { motivational drivers including word-of-mouth activity, } \\
\text { recommendations, customer-to-customer interactions, blogging, } \\
\text { writing reviews and other similar activities. }\end{array}$ \\
\hline
\end{tabular}

Beyond these definitions there is also no consensus regarding the dimensions of consumer engagement. There are so many potential dimensions of consumer engagement and they are summarized in Table 2 below with their conceptual definitions. 
Table 2. Potential Dimensions of Consumer Engagement

\begin{tabular}{|l|l|l|}
\hline Dimension & \multicolumn{1}{|c|}{ Conceptual definition } & \multicolumn{1}{|c|}{ Relevant literature } \\
\hline Identification & $\begin{array}{l}\text { The degree of a consumer's perceived oneness with } \\
\text { or belongingness to the brand (Bhattacharya et al., } \\
\text { 1995) }\end{array}$ & $\begin{array}{l}\text { Hollebeek, 2009; Bakker et al., } \\
\text { 2008; Macey and Schneider, 2008; } \\
\text { Demerouti and Bakker, 2008; } \\
\text { Gonzalez-Roma et al., 2006. }\end{array}$ \\
\hline Attention & $\begin{array}{l}\text { The degree of attentiveness, focus and connection } \\
\text { that a consumer has with the brand. }\end{array}$ & $\begin{array}{l}\text { Hollebeek, 2009; Rothbard, 2001; } \\
\text { Vivek 2009. }\end{array}$ \\
\hline Enthusiasm & $\begin{array}{l}\text { The degree of excitement and interest that a } \\
\text { consumer has in a brand (Vivek, 2009). }\end{array}$ & $\begin{array}{l}\text { Harter et al., 2002; Macey and } \\
\text { Schneider, 2008; Patterson et al., } \\
2006 ; \text { Schaufeli et al., 2002b; Vivek, } \\
\text { 2009; Salanova et al., 2005. }\end{array}$ \\
\hline Absorption & $\begin{array}{l}\text { A pleasant state which describes the customer as } \\
\text { being fully concentrated, happy and deeply } \\
\text { engrossed while playing the role as a consumer of } \\
\text { the brand (Patterson et al., 2006) }\end{array}$ & $\begin{array}{l}\text { Hollebeek, 2009; Patterson et al., } \\
2006 ; \text { Schaufeli and Bakker, 2004; } \\
\text { Rothbard, 2001; Schaufeli et al., } \\
2006 .\end{array}$ \\
\hline Interaction & $\begin{array}{l}\text { A customer's online and offline participation with } \\
\text { the brand organization or other customers outside } \\
\text { of purchase. }\end{array}$ & $\begin{array}{l}\text { Bijmolt et al., 2010; Erat et al., } \\
2006 ; \text { Patterson et al., 2006; } \\
\text { Marketing Science Institute, 2010; } \\
\text { van Doorn et al., 2010; Verhoef et } \\
\text { al., 2010; Wagner and Majchrzak, } \\
\text { 2007. }\end{array}$ \\
\hline
\end{tabular}

In this study, we build upon the conceptual foundation of engagement and various definitions above, and derive a working definition of customer engagement in an online social platform. The conceptualization of engagement embraces three dimensions; cognitive, emotional, and physical (Bowden, 2009; Schaufeli et al., 2002:74; Van Doorn et al., 2010). Therefore, in this study consumer engagement in an online social platform is defined as the level of a customer's physical, cognitive, and emotional presence in connections with a particular online social platform.

- Physical (Vigor) refers to the level of energy and mental resilience while using an online social platform, willingness to invest time and effort in one's role as a customer, (Cheung, Lee and Ling Jin, 2011:3), a good example is a person's ability to use an online social platform for a very long period at a time or to devote a lot of energy on online social platform (Salanova et al., 2005).

- Cognitive (Absorption) refers to being fully concentrated and deeply engrossed in an online social platform, (Cheung, Lee and Ling Jin, 2011:3). For example, forgetting about something else while using an online social platform or when one realizes that time moves so fast because is using online social platform (Salanova et al., 2005; Schaufeli et al., 2002; Rich et al., 2010).

- Emotional (Dedication) refers to a sense of significance, enthusiasm, inspiration, pride, and challenge towards an online social platform, (Cheung, Lee and Ling Jin, 2011:3). For example, when one feels interested, excited, proud and inspired while using online social platform (Schaufeli et al., 2002; Rich et al., 2010; Salanova et al., 2005).

\section{Consequences of Consumer Engagement}

Through the literature review process, we discovered four consequences of consumer engagement: Brand loyalty (Gummerus et al., 2012; Cheung et al., 2012; Bowden, 2009; Malciute, 2012; Madupu and Cooley, 2010; Wirtz et al., 2013), trust (Brodie et al., 2013; Laroche at al., 2012; Vivek, Beatty and Mogan, 2012), satisfaction (Sashi, 2012; Wirtz et al., 2013) and, commitment (Brodie et al., 2013). 


\subsection{Brand Loyalty}

Chaudhuri (1999:137) defines brand loyalty as "a customer's preference to buy a single brand name in a product class". According to Jacoby and Chestnut (1978), brand loyalty is a two-dimensional concept that concerns behavioral and attitudinal aspects. Behavioral is concerned with repeat purchases while attitudinal is largely concerned with some unique value association with a given brand (Chaudhuri and Holbrook, 2001:82). Behavioral brand loyalty normally results in repeat purchases while attitudinal brand loyalty pushes the brand to the consumer closer and more committed to the brand (Chaudhuri and Holbrook, 2001:83). Brand loyalty leads to brand and company strength, increased growth rate and increased company stability (Grönroos, 1994), increased company earnings (Casalo et al., 2007), increased word-of-mouth (Hallowell, 1996), lower price sensibility (Lynch and Ariely, 2000), reduced marketing costs (Griffin, 2002), and lower rates of customers switching to competitors ( $\mathrm{Yi}$ and La, 2004) among other benefits.

According to Chaudhuri and Holbrook (2001:95), interactions, and promotions of a brand through word of mouth would result in brand loyalty especially if the interactions are within a specific brand community. It can therefore be added that social networking sites as platforms for online brand community would foster greater interactions and promote electronic word of mouth due to their abilities to engage with a large online brand community.

According to Malciute (2012:47) brand loyalty is considered to be a consequence of consumer engagement due to its interactive nature with consumers (Brodie et al., 2013:107) in a given brand community. This view is also supported by findings of many studies and researches such as Gummerus et al., 2012; Cheung et al., 2012; Bowden, 2009; Madupu and Cooley, 2010; Wirtz et al., 2013. Consumer engagement contributes to brand loyalty through customer repeat purchases; retentions and brand experience, which enhances brand loyalty behaviors (Hollebeek, 2010; Verhorf et al., 2010). Therefore, the more consumer engagements in brand communities are promoted the stronger the brand loyalty can be achieved (McAlexander et al., 2002 cited by Wirtz et al., 2013:235). So we hypothesize that:

$\mathrm{H}_{1.1}=$ Behavioral consumer engagement positively affects Brand Loyalty

$\mathrm{H}_{1.2}=$ Cognitive consumer engagement positively affects Brand Loyalty

$\mathrm{H}_{1.3}=$ Emotional consumer engagement positively affects Brand Loyalty

\subsection{Brand Satisfaction}

Roberts-Lombard (2009:73) defined customer satisfaction as the degree to which a business's product or service performance matches up to the expectation of the customer. If the performance matches or exceeds the expectations, then the customer is satisfied, if performance is below par then the customer is dissatisfied". Customer satisfaction is influenced by expectations, perceived service and perceived quality (Hu, Kandampully and Juwaheer 2009:115-116).

Chinomona (2013:1305) cited Grisaffe and Nguyen (2011) in defining brand satisfaction to refer to consumer's evaluation based on consumer's total purchase and experience with a brand of a product or service'. This definition recognizes the consumers' brand experiences with the brand in forming a brand satisfaction.

Researchers such as Gummerus et al., (2012) and Brodie et al., (2013) define brand satisfaction as an outcome of consumer engagement. This is mainly due to the effective roles of trust consumers may have in a brand. By recommending others to the brand and expressions of satisfaction could trigger higher confidence levels in a brand hence fostering brand satisfaction (Brodie et al., 2011:7; Brodie et al., 2013). Consumer engagement therefore can be considered to be an important factor leading to brand satisfaction because it enables consumers and brands to interact in a given platform. Additionally, the more value a consumer anticipates and receives from the brand, the higher the levels of brand satisfaction (Wirtz et al., 2013:235). So in this study, based on the literature it is hypothesized that:

$\mathrm{H}_{2.1}=$ Behavioral consumer engagement positively affects Satisfaction 
$\mathrm{H}_{2.2}=$ Cognitive consumer engagement positively affects Satisfaction

$\mathrm{H}_{2.3}=$ Emotional consumer engagement positively affects Satisfaction

\subsection{Brand Commitment}

Rauyruen and Miller (2007:3), defined commitment as "a psychological sentiment of the mind through which an attitude concerning continuation of a relationship with a business partner is formed". Brand commitment refers to an emotional sense of attachment to a brand (Beatty and Kahle, and Homer, 1988). Customer commitment is crucial to long term relationships (Garbarino and Johnson, 1999). Committed customers normally have a feeling of brand relationship, which in most cases bonds them to that brand or company (Moorman et al., 1993) because of those brand relationships are easy to sustain with the presence of a right engaging platform.

Brand commitment is considered to be a consequence of consumer engagement (Brodie et al., 2013; Jahn and Kunz, 2012; Vivek, Beatty and Morgan, 2012; Wirtz et al., 2013:234) that also active in the engagement cycle (Sashi, 2012). Engaged consumers are most likely to be committed to a given brand due to the constant patronage and interactions with the brand especially if the right engagement platform is used. Therefore, it can be argued that consumer engagement in virtual or online brand communities such as SNS could result in more brand commitment behaviors by the consumers. So we hypothesize that:

$\mathrm{H}_{3.1}=$ Behavioral consumer engagement positively affects Commitment

$\mathrm{H}_{3.2}=$ Cognitive consumer engagement positively affects Commitment

$\mathrm{H}_{3.3}=$ Emotional consumer engagement positively affects Commitment

\subsection{Brand Trust}

Thomas (2009: 346) defined trust as "an expectancy of positive outcomes, outcomes that one can receive based on the expected action of another party". Trust is important in reducing risk perceptions from consumers regarding a brand or product. Brand trust is "the willingness of the average consumer to rely on the ability of the brand to perform its stated function" (Chaudhuri and Holbrook 2001:82). Brand trust was considered to be a result of repeated interactions and mutual brand-customer relationships (McAlexander et al., 2002; Laroche et al., 2013:80) that in a given brand community (Laroche et al., 2012:1759; Laroche et al., 2013:78) and it is also believed that brand trust plays a significant role in minimizing risk perceptions associated with the brand (Chaudhuri and Hollbrook, 2001) especially when consumers are engaged.

Brand trust was considered to be an outcome of consumer engagement (see Brodie et al., 2013; Casalo, Flavian and Guinaliu, 2007; Laroche et al. 2012; Vivek, Beatty and Morgan, 2012). This is because brand trust in brand community rotates around the level of engagement with the consumers in a given social platform (Habibi et al., 2014:155). It is through consumer engagement especially through SNS such as brand pages that brand to customer; customer to customer; interactions are enhanced. The more such engagement behaviors are exercised in a given brand community, the more it builds and results in brand trust, (Habibi et al., 2013:159). Therefore, in respect to consumer engagement dimensions, we hypothesize that:

$\mathrm{H}_{4.1}=$ Behavioral consumer engagement positively affects Trust

$\mathrm{H}_{4.2}=$ Cognitive consumer engagement positively affects Trust

$\mathrm{H}_{4.3}=$ Emotional consumer engagement positively affects Trust

\section{Methodology}

A survey was constructed and administered to the users of the Facebook brand communities. Facebook brand pages are chosen as an example of the virtual community in SNS because Facebook stands out as the mostly used social networking site (see Atabek, 2013:21; Özata and Er, 2015; Argan and Akyıldız, 2012) and due to its enormous engaging capability and usability in Turkey. 


\subsection{Research Model}

A research model also explained in the literature part is developed after reviewing various literature and secondary data. The model aims to test if three dimensions of consumer engagement (cognitive, behavioral and emotional) with each variable having a probable effect on brand loyalty, commitment, satisfaction and trust.

Figure 1. Research Model

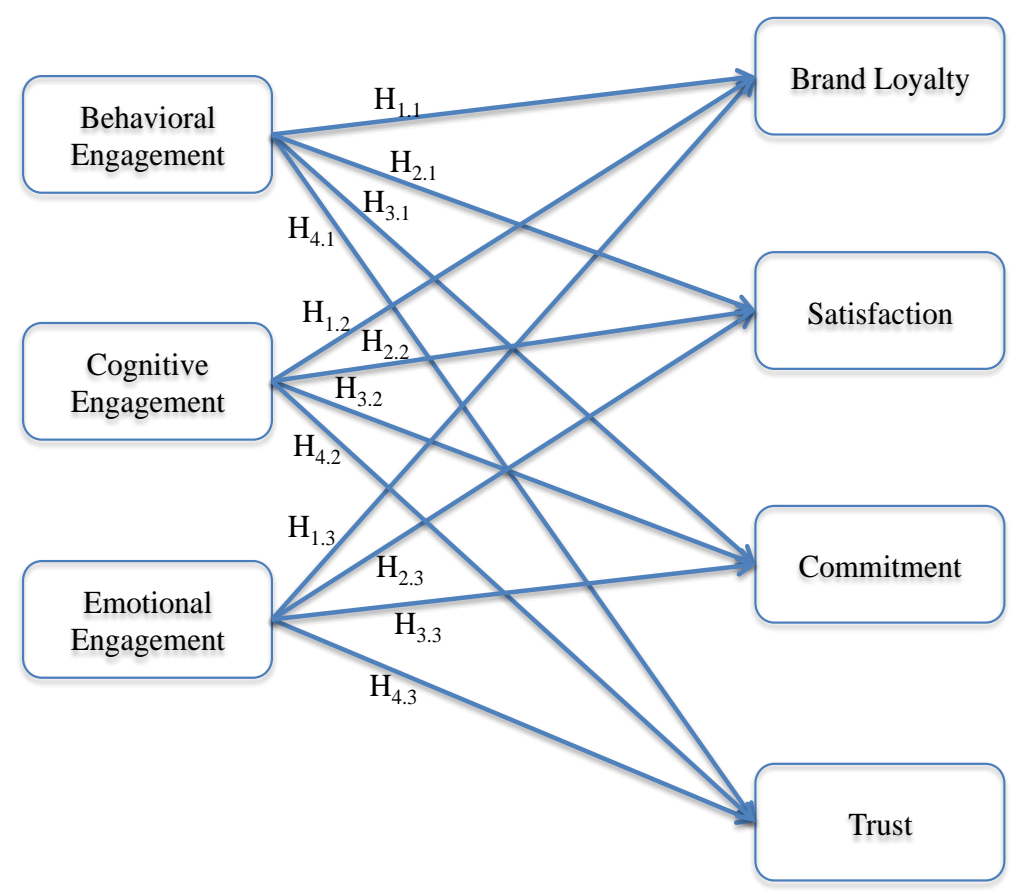

\subsection{Data Collection Tool and Measures}

Our questionnaire was consisting four parts. In the first part we emphasized the aim of the research and also give details about the research. In the second part we asked participants to define if they have a Facebook account or not. If the participant has no Facebook account, they did not fill the questionnaire. If the respondent has a Facebook account, they are asked if they liked a Facebook brand page or not. The participants who said that they didn't ever like a Facebook brand page also did not answer the questionnaire. Then we asked the respondents to define 3 Facebook brand pages they have liked and choose one of them (most followed and engaged). In the third part respondents are required to answer scale items related to the constructs considering the Facebook page they have chosen. In the fourth part we asked questions related to their demographic profile and social media usage. The questionnaire contained a total of 53 questions and it took 5-7 minutes to answer.

To measure the constructs in the model, items were drawn from relevant scales. Table 3 shows the scales used to measure the constructs in the model. Various items as shown below used to measure each variable. The statements were measured on five-point scales with the anchors "completely disagree""completely agree".

The constructs were factor analyzed to explore the factor structure of engagement dimensions and consequences and to check for construct validity of the relationship measures. The final items that were used in the analyses are presented in the table (Appendix A) together with their respective factor loadings and Cronbach's a reliability statistics for all constructs. In the study none of the Cronbach's alpha value was below 0.8 , which signifies a good internal consistency. 
The Consequences of Consumer Engagement in Social Networking Sites

Table 3. Variables and Scales Used

\begin{tabular}{|l|l|l|}
\hline Variable & Reference(s) & $\begin{array}{l}\text { Number of } \\
\text { Items }\end{array}$ \\
\hline Behavioral Dimension & Cheung, Lee, and Jin, 2011, Malciute, 2012 & 6 \\
\hline Emotional Dimension & Cheung, Lee, and Jin, 2011; Malciute, 2012 & 5 \\
\hline Cognitive Dimension & Cheung, Lee, and Jin, 2011; Malciute, 2012 & 6 \\
\hline Brand Loyalty (Attitudinal) & $\begin{array}{l}\text { Vivek 2009; Reitz 2012; } \\
\text { Malciute, 2012; Chaudhuri and Holbrook, 2001 }\end{array}$ & 6 \\
\hline Commitment (Affective) & Vivek, 2009 & 3 \\
\hline Satisfaction & $\begin{array}{l}\text { Malciute, 2012; } \\
\text { Gustafsson et al., 2005 }\end{array}$ & 3 \\
\hline Trust & $\begin{array}{l}\text { Malciute, 2012; } \\
\text { Chaudhuri and Holbrook, 2001 }\end{array}$ \\
\hline
\end{tabular}

Table 4. Demographic Characteristics and Social Media Usage Rates of Respondents

\begin{tabular}{|c|c|c|}
\hline & $\mathrm{N}$ & $\%$ \\
\hline \multicolumn{3}{|l|}{ Gender ( $n=387)$} \\
\hline Female & 166 & 42.9 \\
\hline Male & 221 & 57.1 \\
\hline \multicolumn{3}{|l|}{ Age $(n=387)$} \\
\hline $18-20$ & 37 & 9.6 \\
\hline $21-22$ & 152 & 20.2 \\
\hline $23-24$ & 117 & 30.3 \\
\hline$>25$ & 81 & 39.9 \\
\hline \multicolumn{3}{|c|}{$\begin{array}{lll}\text { Use of Social Media (Daily) } \\
(n=387)\end{array}$} \\
\hline Less than $30 \mathrm{~min}$. & 15 & 3.9 \\
\hline 30 min-1 hour & 51 & 13.2 \\
\hline 1-2 hours & 120 & 31 \\
\hline $2-3$ hours & 107 & 27.6 \\
\hline More than 3 hours & 94 & 24.3 \\
\hline \multicolumn{3}{|c|}{ Use of Facebook (Daily) (n=387) } \\
\hline Less than $30 \mathrm{~min}$. & 109 & 28.2 \\
\hline 30 min-1 hour & 136 & 35.1 \\
\hline $1-2$ hours & 64 & 16.5 \\
\hline $2-3$ hours & 43 & 11.1 \\
\hline More than 3 hours & 35 & 9 \\
\hline \multicolumn{3}{|c|}{$\begin{array}{l}\text { Other social media usage } \\
(n=387)\end{array}$} \\
\hline Twitter & 264 & 68.2 \\
\hline LinkedIn & 103 & 26.6 \\
\hline Google+ & 167 & 43.2 \\
\hline YouTube & 299 & 77.3 \\
\hline Instagram & 296 & 76.5 \\
\hline Pinterest & 70 & 18.1 \\
\hline Foursquare & 129 & 33.3 \\
\hline Tumbler & 37 & 9.6 \\
\hline
\end{tabular}




\subsection{Sample Characteristics}

The universe of research was university students' from a middle-sized university in Eskişehir, Turkey. This sample was chosen because they form the most social media-using group and they form the most engaging part of the population (Argan and Akyıldız, 2011). The sample population was also chosen for it offers the most convenient area for the researcher in terms of accessibility, familiarity and easiness since during data collection students were readily available. A total of 400 students answered the questionnaire and of these 387 were valid. The descriptive statistics of customer engagement behaviors are shown in Table 4.

Descriptive analyses were conducted with a total of 387 questionnaires after removing 13 respondents' questionnaire, which indicate they don't like any Facebook brand page. Sample demographics results show that out of the 387 respondents, 166 were female students representing $42.9 \%$ and 221 were male representing $57.1 \%$, which showed generally balanced gender participation. The results further indicate that respondents between ages groups of 18-20 years represented a 9.6\%, those between 21-22 years represented $20.2 \%$, respondents between $23-24$ years represented $30.3 \%$, while respondents above 25 years represented $39.9 \%$. This age brackets sample indicated a generally young population. The majority of the respondents spend more than 1 hour on social media daily and respondents are active social media users.

\section{Findings}

In order to test the hypothesis in the research model, regression analyses were conducted. Before regression, factor analysis was also conducted to ensure the discriminant validity. In our study, factor analysis supports the constructs as separate measures (see Appendix). To determine possible complications before regression, a correlation analysis is conducted. Table 5 shows the Pearson Correlations. As expected and hypothesized all dimensions of customer engagement (independent variables) are correlated with the dependent variables loyalty, satisfaction, commitment and trust. On the other hand, most studies in the area of loyalty show that loyalty, satisfaction, trust and commitment are also very related constructs.

Table 5. Correlation Analysis for All Variables

\begin{tabular}{|c|c|c|c|c|c|c|c|}
\hline & 1 & 2 & 3 & 4 & 5 & 6 & 7 \\
\hline 1. Cognitive $C E$ & 1 & $.621^{* *}$ & $.546^{* *}$ & $.387^{* *}$ & $.241^{* *}$ & $.551^{* *}$ & $.360^{* *}$ \\
\hline 2. Behavioral CE & $.621^{* *}$ & 1 & $.505^{* *}$ & $.401^{* *}$ & $.257^{* *}$ & $.581^{* *}$ & $.398^{* *}$ \\
\hline 3. Emotional CE & $.546^{* *}$ & $.505^{* *}$ & 1 & $.384^{* *}$ & $.365^{* *}$ & $.412^{* *}$ & $.456^{* *}$ \\
\hline 4. Loyalty & $.387^{* *}$ & $.401^{* *}$ & $.384^{* *}$ & 1 & $.613^{* *}$ & $.432^{* *}$ & $.502^{* *}$ \\
\hline 5. Satisfaction & $.241^{* *}$ & $.257^{* *}$ & $.365^{* *}$ & $.613^{* *}$ & 1 & $.337^{* *}$ & $.563^{* *}$ \\
\hline 6. Commitment & $.551^{* *}$ & $.581^{* *}$ & $.412^{* *}$ & $.432^{* *}$ & $.337^{* *}$ & 1 & $.483^{* *}$ \\
\hline 7. Trust & $.360^{* *}$ & $.398^{* *}$ & $.456^{* *}$ & $.502^{* *}$ & $.563^{* *}$ & $.483^{* *}$ & 1 \\
\hline
\end{tabular}

** Correlation is significant at the 0.01 level (2-tailed).

\subsection{Brand Loyalty}

It is hypothesized that behavioral, emotional and cognitive engagements affect brand loyalty. A linear regression test was run using behavioral, emotional and cognitive engagement as independent variables and brand loyalty as dependent variable. This model is used in testing hypothesis 1.1,1.2 and 1.3. The results are summarized in Tables 6 below for the results of regression analysis. ANOVA results show that the model is found to be significant $(P=0.000)$. The model is capable of explaining $\% 22$ of the variance in brand loyalty ( $R$ square value). Test of coefficients of independent variables shows that while behavioral $(P=0.001)$ and emotional $(P=0.000)$ engagement are found to be significant, but cognitive engagement $(P=0.015)$ is not found to be a significant predictor variable for brand loyalty. 
The Consequences of Consumer Engagement in Social Networking Sites

Table 6. Results of Regression Analysis for Brand Loyalty

\begin{tabular}{|c|c|c|c|c|c|}
\hline \multicolumn{6}{|l|}{ Model Summary } \\
\hline & $\mathbf{R}$ & $\mathbf{R}^{2}$ & Adjusted $\mathbf{R}^{2}$ & $\begin{array}{l}\text { Std. Error of } \\
\text { the Estimate }\end{array}$ & \\
\hline Model & $.466^{\mathrm{a}}$ & .217 & .211 & .71532 & \\
\hline \multicolumn{6}{|l|}{ ANOVA Model $^{\mathrm{b}}$} \\
\hline & Sum of Squares & df & Mean Square & $\mathbf{F}$ & Sig. \\
\hline Regression & 54.418 & 3 & 18.139 & 35.450 & $.000^{\circ}$ \\
\hline Residual & 195.973 & 383 & .512 & & \\
\hline Total & 250.391 & 386 & & & \\
\hline \multicolumn{6}{|l|}{ Coefficients $^{\mathrm{b}}$} \\
\hline & \multicolumn{2}{|c|}{ Unstandardized Coefficients } & Standardized Coefficients & & \\
\hline & B & Std. Error & Beta & $\mathbf{t}$ & Sig. \\
\hline (Constant) & 1.869 & .180 & & 10.399 & .000 \\
\hline COGNITIVE CE & .119 & .049 & .150 & 2.439 & .015 \\
\hline BEHAVIORAL CE & .193 & .055 & .209 & 3.505 & .001 \\
\hline EMOTIONAL CE & .214 & .061 & .197 & 3.528 & .000 \\
\hline
\end{tabular}

Notes: a. Predictors: (Constant), EMOTIONAL CE, BEHAVIORAL CE, COGNITIVE CE; b. Dependent Variable: BRAND LOYALTY.

\subsection{Satisfaction}

In the second part, it is hypothesized that behavioral, emotional and cognitive engagements affect satisfaction. A linear regression test was run using behavioral, emotional and cognitive engagement as independent variables and satisfaction as dependent variable. This model is used in testing hypothesis 2.1, 2.2 and 2.3. The results are summarized in Tables 7 below for the results of regression analysis. ANOVA results show that the model is found to be significant $(P=0.000)$. The model is capable of explaining \%14 of the variance in satisfaction ( $R$ square value). Test of coefficients of independent variables shows that only emotional engagement $(P=0.000)$ is found to be significant, but cognitive $(P=0.806)$ and behavioral $(P=0.148)$ engagement are not found to be a significant predictor variable for satisfaction.

Table 7. Results of Regression Analysis for Satisfaction

\begin{tabular}{|c|c|c|c|c|c|}
\hline \multicolumn{6}{|l|}{ Model Summary } \\
\hline & $\mathbf{R}$ & $\mathbf{R}^{2}$ & Adjusted $\mathbf{R}^{2}$ & $\begin{array}{l}\text { Std. Error of } \\
\text { the Estimate }\end{array}$ & \\
\hline Model & $.374^{a}$ & .140 & .134 & .71795 & \\
\hline \multicolumn{6}{|l|}{ ANOVA Model ${ }^{b}$} \\
\hline & Sum of Squares & df & Mean Square & $\mathbf{F}$ & Sig. \\
\hline Regression & 32.203 & 3 & 10.734 & 20.825 & $.000^{\mathrm{a}}$ \\
\hline Residual & 197.420 & 383 & .515 & & \\
\hline Total & 229.623 & 386 & & & \\
\hline \multicolumn{6}{|l|}{ Coefficients $^{b}$} \\
\hline & \multicolumn{2}{|c|}{ Unstandardized Coefficients } & Standardized Coefficients & & \\
\hline & B & Std. Error & Beta & $\mathbf{t}$ & Sig. \\
\hline (Constant) & 2.334 & .180 & & 12.939 & .000 \\
\hline COGNITIVE CE & .012 & .049 & .016 & .245 & .806 \\
\hline BEHAVIORAL CE & .080 & .055 & .090 & 1.448 & .148 \\
\hline EMOTIONAL CE & .323 & .061 & .310 & 5.310 & .000 \\
\hline
\end{tabular}

Notes: a. Predictors: (Constant), EMOTIONAL CE, BEHAVIORAL CE, COGNITIVE CE; b. Dependent Variable: SATISFACTION. 


\subsection{Commitment}

It is hypothesized that behavioral, emotional and cognitive engagements affect commitment. A linear regression test was run using behavioral, emotional and cognitive engagement as independent variables and commitment as dependent variable. This model is used in testing hypothesis 3.1, 3.2 and 3.3. The results are summarized in Tables 8 below for the results of regression analysis. ANOVA results show that the model is found to be significant $(P=0.000)$. The model is capable of explaining $\% 40$ of the variance in commitment ( $R$ square value). Test of coefficients of independent variables shows that cognitive $(P=0.000)$ and behavioral $(P=0.000)$ engagement are found to be significant, but emotional engagement $(P=0.150)$ is not found to be a significant predictor variable for commitment.

Table 8. Results of Regression Analysis for Commitment

\begin{tabular}{|c|c|c|c|c|c|}
\hline \multicolumn{6}{|l|}{ Model Summary } \\
\hline & $\mathbf{R}$ & $\mathbf{R}^{2}$ & Adjusted $\mathrm{R}^{2}$ & $\begin{array}{l}\text { Std. Error of } \\
\text { the Estimate }\end{array}$ & \\
\hline Model & $.632^{a}$ & .400 & .395 & .90053 & \\
\hline \multicolumn{6}{|l|}{ ANOVA Model ${ }^{b}$} \\
\hline & Sum of Squares & df & Mean Square & $\mathbf{F}$ & Sig. \\
\hline Regression & 206.888 & 3 & 68.963 & 85.039 & $.000^{\mathrm{a}}$ \\
\hline Residual & 310.595 & 383 & .811 & & \\
\hline Total & 517.484 & 386 & & & \\
\hline \multicolumn{6}{|l|}{ Coefficients $^{b}$} \\
\hline & \multicolumn{2}{|c|}{ Unstandardized Coefficients } & Standardized Coefficients & & \\
\hline & B & Std. Error & Beta & $\mathbf{t}$ & Sig. \\
\hline (Constant) & .266 & .226 & & 1.174 & .241 \\
\hline COGNITIVE CE & .325 & .062 & .283 & 5.263 & .000 \\
\hline BEHAVIORAL CE & .491 & .069 & .370 & 7.083 & .000 \\
\hline EMOTIONAL CE & .110 & .076 & .070 & 1.441 & .150 \\
\hline
\end{tabular}

Notes: a. Predictors: (Constant), EMOTIONAL CE, BEHAVIORAL CE, COGNITIVE CE; b. Dependent Variable: COMMITMENT.

Table 9. Results of Regression Analysis for Trust

\begin{tabular}{|c|c|c|c|c|c|}
\hline \multicolumn{6}{|l|}{ Model Summary } \\
\hline & $\mathbf{R}$ & $\mathbf{R}^{2}$ & Adjusted $\mathrm{R}^{2}$ & $\begin{array}{l}\text { Std. Error of } \\
\text { the Estimate }\end{array}$ & \\
\hline Model & $.498^{\mathrm{a}}$ & .248 & .242 & .71436 & \\
\hline \multicolumn{6}{|l|}{ ANOVA Model ${ }^{b}$} \\
\hline & Sum of Squares & df & Mean Square & $\mathbf{F}$ & Sig. \\
\hline Regression & 64.349 & 3 & 21.450 & 42.033 & $.000^{\mathrm{a}}$ \\
\hline Residual & 195.448 & 383 & .510 & & \\
\hline Total & 259.797 & 386 & & & \\
\hline \multicolumn{6}{|l|}{ Coefficients $^{b}$} \\
\hline & \multicolumn{2}{|c|}{ Unstandardized Coefficients } & Standardized Coefficients & & \\
\hline & B & Std. Error & Beta & $\mathbf{T}$ & Sig. \\
\hline (Constant) & 1.944 & .179 & & 10.834 & .000 \\
\hline COGNITIVE CE & .050 & .049 & .061 & 1.012 & .312 \\
\hline BEHAVIORAL CE & .185 & .055 & .197 & 3.370 & .001 \\
\hline EMOTIONAL CE & .357 & .060 & .323 & 5.912 & .000 \\
\hline
\end{tabular}

Notes: a. Predictors: (Constant), EMOTIONAL CE, BEHAVIORAL CE, COGNITIVE CE; b. Dependent Variable: TRUST. 


\subsection{Trust}

It is hypothesized that behavioral, emotional and cognitive engagements affect trust. A linear regression test was run using behavioral, emotional and cognitive engagement as independent variables and trust as dependent variable. This model is used in testing hypothesis 4.1, 4.2 and 4.3. The results are summarized in Tables 9 below for the results of regression analysis. ANOVA results show that the model is found to be significant $(P=0.000)$. The model is capable of explaining $\% 25$ of the variance in trust. Test of coefficients of independent variables shows that behavioral $(P=0.001)$ and emotional $(P=0.000)$ engagement are found to be significant, but cognitive engagement $(P=0.312)$ is not found to be a significant predictor variable for trust.

The summary of the test of the research hypothesis is shown below in Table 10. As shown 7 out of $12(\mathrm{H} 1.1, \mathrm{H} 1.3, \mathrm{H} 2.3, \mathrm{H} 3.1, \mathrm{H} 3.2, \mathrm{H} 4.1$ and H4.3) hypothesis are supported. Depending on the hypothesis testing, the final model of the study is also shown in Figure 2.

Table 10. Summary of Research Hypothesis

\begin{tabular}{|c|c|c|}
\hline Hypothesis & Sub-Hypothesis and Description & Results \\
\hline \multirow[b]{3}{*}{$\mathrm{H}_{1}$} & $\mathrm{H}_{1.1}=$ Behavioral consumer engagement positively affects Brand Loyalty & Supported \\
\hline & $\mathrm{H}_{1.2}=$ Cognitive consumer engagement positively affects Brand Loyalty & Not supported \\
\hline & $\mathrm{H}_{1.3}=$ Emotional consumer engagement positively affects Brand Loyalty & Supported \\
\hline \multirow[b]{3}{*}{$\mathbf{H}_{2}$} & $\mathrm{H}_{2.1}=$ Behavioral consumer engagement positively affects Satisfaction & Not supported \\
\hline & $\mathrm{H}_{2.2}=$ Cognitive consumer engagement positively affects Satisfaction & Not supported \\
\hline & $\mathrm{H}_{2.3}=$ Emotional consumer engagement positively affects Satisfaction & Supported \\
\hline \multirow[b]{3}{*}{$\mathbf{H}_{3}$} & $\mathrm{H}_{3.1}=$ Behavioral Consumer engagement positively affects Commitment & Supported \\
\hline & $\mathrm{H}_{3.2}=$ Cognitive Consumer engagement positively affects Commitment & Supported \\
\hline & $\mathrm{H}_{3.3}=$ Emotional Consumer engagement positively affects Commitment & Not supported \\
\hline \multirow{3}{*}{$\mathbf{H}_{4}$} & $\mathrm{H}_{4.1}=$ Behavioral consumer engagement positively affects Trust & Supported \\
\hline & $\mathrm{H}_{4.2}=$ Cognitive consumer engagement positively affects Trust & Not supported \\
\hline & $\mathrm{H}_{4.3}=$ Emotional consumer engagement positively affects Trust & Supported \\
\hline
\end{tabular}

Figure 2. Final Model

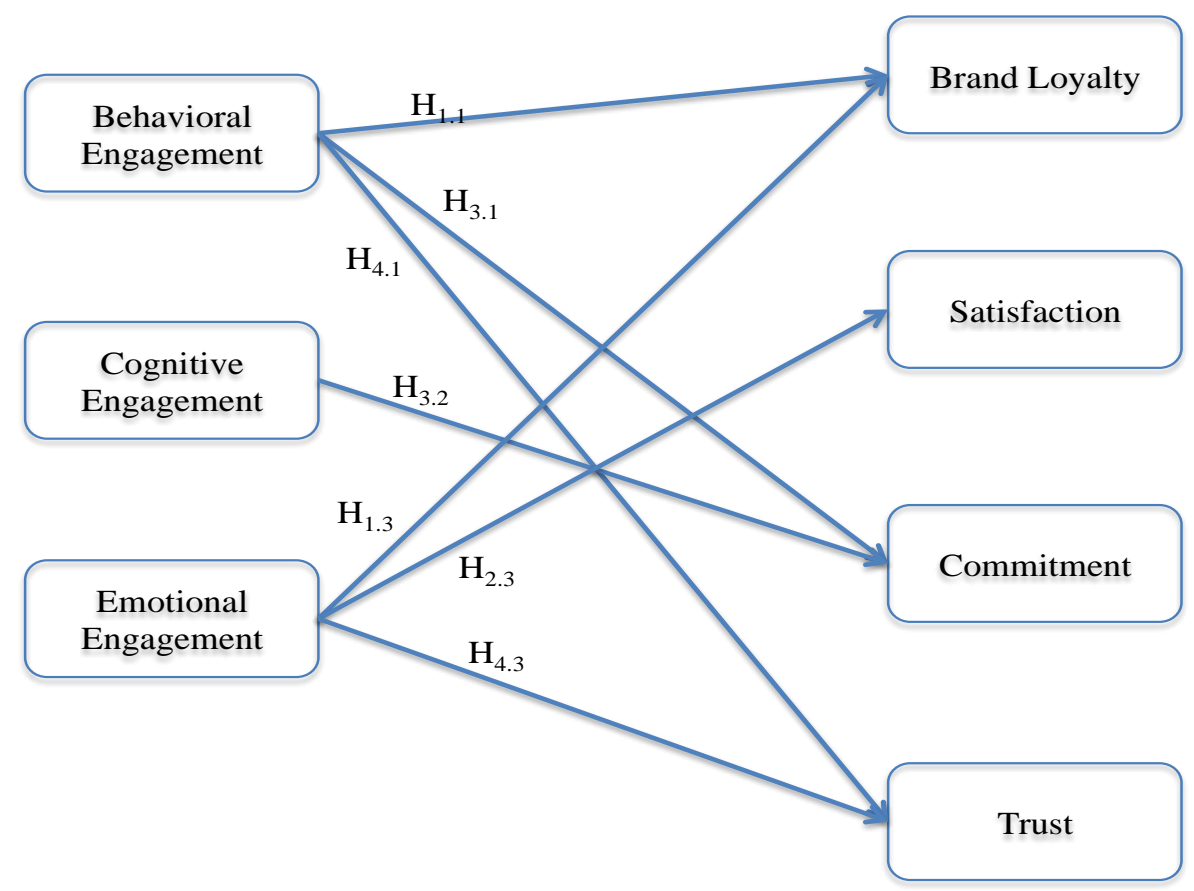




\section{Discussions, Implications and Conclusions}

This study attempted to find out the consequences of consumer engagement in social networking sites such brand pages with a broadened outlook of consumer engagement to be composed of three important dimensions of behavioral, cognitive and emotional consumer engagement. Consequently, the findings of the study suggest that brand loyalty, satisfaction, commitment, and trust are possible consequences of consumer engagement in social networking sites. This finding is in line with earlier researchers such as Brodie et al. (2011). And as a result of this study, it was also possible to determine the effect of each of the three consumer engagement dimensions on the probable consequences of consumer engagement and therefore the findings have provided an important milestone to be able to determine which dimension of consumer engagement is more effective and later on be treated more seriously to increase brand loyalty, satisfaction, commitment, and trust.

In the first hypothesis, it was hypothesized that behavioral, cognitive and emotional consumer engagement positively affects brand loyalty. According to the findings, behavioral and emotional consumer engagement dimensions were both found to be significant predictors for brand loyalty while cognitive consumer engagement was not found to be significant. This explains why emotional factors such as exciting, interesting, and well designed contents in brand posts would lead to behavioral actions of regular shares, comments, visits, and active interactions between brands and consumers and also among consumers and prospects (Doorn et al., 2010:255; Gummerus et al, 2012:858). Whereas these kinds of emotional and behavioral engagement behaviors could be supported and enhanced, perhaps consumers do not stay long with brand pages in terms of the time they spend on brand pages and other online platforms. This perhaps explains why cognitive consumer engagement is not a significant predictor of brand loyalty and therefore was not supported $(p=0.015)$. Therefore, in summary, factors that are associated with emotional and behavioral engagement dimensions would result in brand loyalty more than cognitive engagement factors.

The second hypothesis was that behavioral, cognitive and emotional consumer engagement positively affected satisfaction. According to the findings, emotional consumer engagement was found to be a significant predictor for satisfaction. Behavioral and cognitive consumer engagement dimensions were however found not to be significant predictors of satisfaction. This can be interpreted to mean that emotional consumer engagement offers an exciting, interesting and more entertainment relationship benefits which are believed to have an effect on the satisfaction levels of the consumer (Gummerus et al., 2012:858).

The third hypothesis was that behavioral, cognitive and emotional consumer engagement positively affected commitment. The results show that cognitive and behavioral consumer engagement was found to be significant predictors for commitment while emotional was not found to be significant. It can be argued that online behavioral and cognitive actions such as regular online visits, spending a lot of time on brand pages through comments, shares, online brand -consumer interactions tend to result in more (affective) commitment behaviors because of the feeling of the sense of belongingness to the brand and a perception of an existence of a virtual brand relationship (Wirtz et al., 2013). It can therefore be concluded that among the three dimensions of consumer engagement, behavioral and cognitive consumer engagement dimension suggest having more effect on the consequence of commitment. It can also be added that since the $r$ square of commitment construct was $40 \%$, perhaps it could also add to the suggestions of the earlier findings that commitment is an outcome of consumer engagement (e.g Wirtz et al., 2013; Brodie et al., 2011; Jahn and Kunz, 2012; Vivek, Beatty and Morgan, 2012) and therefore the more consumers are engaged online the more they become committed to the brand (Kim et al., 2008 cited by Wirtz et al., 2013:235) especially if engaged through the right platforms.

The fourth hypothesis was that behavioral, cognitive and emotional consumer engagement positively affected trust. The results show that behavioral and emotional consumer engagement dimensions were found to be significant predictors for trust while cognitive consumer engagement dimension was not. The emotional and behavioral actions represented through sharing brand related posts, provision of necessary online information either from the brand or from fellow consumers, online consumer interactions, inspiring 
and exciting contents develop and strengthen not only relationships (Habibi et al., 2014) but also enhance brand trust (Casalo et al., 2007; Hollebeek, 2011; Brodie et al., 2011).

It is also hoped that the findings of this study will be useful not only to the academia through knowledge additions to the field of consumer engagement, but also to the managers and marketing practitioners. Managers will be able to determine which engagement platforms to use to achieve what. Companies and brand managers should focus on both behavioral and emotional engagement because these two dimensions were found to be more significant for predicting brand loyalty. Therefore, to increase brand loyalty, this study recommends more focus on both behavioral and emotional engagement. To improve on and achieve higher levels of consumer satisfaction, companies and brand managers should also focus on emotional engagement dimension. This is because it was found to be a significant contributor to consumer satisfaction. To increase on both the commitment of consumers and develop a long term consumer brand commitment, this study recommends that companies and brand managers focus more on cognitive and behavioral engagement dimensions because they showed to be more significant factors leading to commitment. It should be noted that the more consumers are engaged the more they become committed to the brand. Therefore, brands should engage consumers more often to increase the commitment of their consumers. Brands and companies need to take the issue of trust as a valuable factor to consolidate customers, strengthen brand loyalty, and enhance brand-consumer relationship. They should develop and earn trust from their consumers. According to this study, behavioral and emotional engagement dimensions were found to have a greater significance in bringing about brand trust, It is therefore recommended that brands concentrate on these two dimensions.

To the companies and brands that intend to employ viral marketing or Internet marketing, consumer engagement in SNS offers an effective and conducive environment in the way that social media platforms that consumers use, are easily to engage customers from and be able to reap results.

\section{End Notes}

1. This study is produced from the unpublished master thesis of Abubakar Lujja named "The Consequences of Consumer Engagement in Social Networking Sites".

\section{References}

Algesheimer, R., Dholakia, U.M., \& Herrmann, A. (2005). The social influence of brand communities: Evidence from European Car Clubs. Journal of Marketing, 59(3),19-34.

Berthon, P., Pitt, L.F., \& Campell, C. (2008). When customers create the ad. California Management Review, 50(4),6-30.

Brodie, R.J., \& Hollebeek, L.D. (2011). Advancing and consolidating knowledge about customer engagement. Journal of Service Research, 14(3),283-4.

Brodie, R.J., Hollebeek, L.D., Biljana, J., \& Ilic, A. (2011a). Customer Engagement: Conceptual Domain, Fundamental Propositions, and Implications for Research, Journal of Service Research, 14(3),252-71.

Brodie, R.J., Ilic, A., Biljana, J., \& Hollebeek, L. (2011b). Consumer \&: An exploratory analysis. Journal of Business Research, 66(2013), 105-114.

Bowden, J. L., (2009). The process of customer engagement: A conceptual framework. Journal of Marketing Theory and Practice, 17(1),63-74.

Boyd, D., \& Ellison, N. (2008). Social network sites: Definition, history, and scholarship. Journal of Computer-Mediated Communication, 13(1),210-30.

Casaló, L., Flavián, C., \& Guinalíu M. (2007). The impact of participation in virtual brand communities on consumer trust and loyalty. Online Information Review, 31(6),775 - 792; Retrieved January 10 2016, from http://dx.doi.org/10.1108/14684520710841766

Chaudhuri, A., \& Holbrook, M. B. (2001). The chain of effects from brand trust and brand effect to brand performance: The role of brand loyalty. Journal of Marketing, 65(2),81-93. 
Cheung, C., Lee, M., \& Jin, X.-L. (2011). Customer engagement in an online social platform: Conceptual model and scale development. Thirty Second International Conference on Information Systems. Shanghai: Online Communities and Digital Collaborations.

Constantinides, E., \& Fountain S., (2007). Web 2.0: Conceptual foundations and marketing issues. Journal of Direct, Data and Digital Marketing Practice, 9(3),231-244.

Ellison, N.B., Charles, S., \& Lampe, C. (2007). The benefits of Facebook 'friends': Social capital and college students' use of online social network sites, Journal of Computer-Mediated Communication, 12(11),43-68.

Ellison, N., Heino, R., \& Gibbs, J. (2006). Impressions online: self-presentation processes in the online dating environment. Journal of Computer-Mediated Communication, 11(2), 2.

Facebook (2012b). Best Practice Guide: Marketing on Facebook, Retrieved November 15, 2015, from http://www.ads.ak.facebook.com/ads/FacebookAds/Best_Practice_Guide_042811_10.pdf

Fornell, C. (1992). A national satisfaction barometer: The Swedish experience. Journal of Marketing, 56(1), 6-21.

Forrester Consulting (2008). How engaged are your customers?: Retrieved May 12, 2016, from www.adobe.com/engagement/pdfs/Forrester_TLP_How_Engaged_Are_Your_Customers.pdf.

Garbarino, E., \& Johnson, M. (1999). The different roles of satisfaction, trust and commitment in customer relationships. Journal of Marketing, 63(2), 70-87.

Grönroos, C. (1994). From marketing mix to relationship marketing: Towards a paradigm shift in marketing. Management Decision, 29(1),7-13.

Gummerus, J., Liljander, V., Weman, E., \& Pihlstrom, M. (2012). Customer engagement in a Facebook brand community. Management Research Review, 35,857-877.

Habibi, M. R., Laroche, M., \& Richard, M.-O. (2014). Brand communities based in social media: How unique are they? Evidence from two exemplary brand communities. International Journal of Information Management, 34(2),123132.

Habibi, M.R, Laroche, M., \& Richard. M. O, (2014). The roles of brand community and community engagement in building brand trust on social media. Computers in Human Behavior 37 (2014),152-161.

Hollebeek, L. D., (2011). Demystifying customer engagement: Exploring the loyalty nexus. Journal of Marketing Management, 27(7-8),785-807.

Jacoby, J., \& Chestnut, R. (1978). Brand loyalty measurement and management, New York: Wiley.

Kaplan, A.M., \& Haenlein, M. (2010). Users of the world, unite! The challenges and opportunities of social media. Business Horizons, 53, 59-68.

Kirby, J., \& Marsden, P. (2005). Connected marketing: the viral, buzz and word of mouth revolution, Oxford, Taylor and Francis.

Laroche, M., Habibi, M. R., \& Richard, M. (2013). To be or not to be in social media: How brand loyalty is affected by social media? International Journal of Information Management, 33, 76- 82.

Laroche, M., Habibi, M.R., Richard, M. O., \& Sankaranarayanan, R. (2012). The effects of social media based brand communities on brand community markers, value creation practices, brand trust and brand loyalty, Computers in Human Behavior, 28, 755-1767.

Lynch, J., \& Ariely, D. (2000). Wine online: Search costs affect competition on price quality and distribution. Marketing Science, 19(1), 83-103.

Madupu, V., \& Cooley, D.O. (2010). Antecedents and consequences of online brand community participation: A conceptual framework. Journal of Internet Commerce, 9 (2),127-147.

Marsden, P. (2010a). Social commerce: Monetizing social media, syzygy group. http://www.syzygy.net

Malciute, J. (2012). Customer brand engagement on online social media platforms- a conceptual model and empirical analysis. Master Thesis, Aarhus University.

McAlexander, J.H., Schouten, J.W., \& Koening, H.F. (2002). Building brand community. Journal of Marketing, 66(1),3854.

McEwen, W. (2004). Why satisfaction isn't satisfying. Gallup Management Journal Online, Retrieved January 20, 2016, from http://gmj.gallup.com/content/14023/Why-Satisfaction-Isnt-Satisfying.aspx.

Moorman, C., Desphande, R., \& Zaltman, G. (1993). Factors affecting trust in market research relationships. Journal of Marketing, 57(1), 81-101.

Muniz Jr., A. M., \& O'Guinn, T. C. (2001). Brand community. Journal of Consumer Research, 27(4),412-432. 
Patterson, P., Yu, T., \& Ruyter, K.d. (2006). Understanding customer engagement in services. Proceedings of the Australian and New Zealand Marketing Academy Conference: Advancing Theory, Maintaining Relevance, Brisbane.

Salanova, M., Agut, S., \& Peiro, J.M.a. (2005). Linking organizational resources and work engagement to employee performance and customer loyalty: the mediation of service climate. Journal of Applied Psychology, 90(6),12171227.

Sashi, C.M. (2012). Customer engagement, buyer-seller relationships, and social media. Management Decision, 50(2), 253-272.

Schaufeli, W., Salanova M, Vincente G-R, \& Arnold B., (2002). The measurement of engagement and burnout: A two sample confirmatory factor analytic approach. Journal of Happiness Studies, 3 (1), 71-92.

Schouten, J.W., \& McAlexander, J. H. (1995). Subcultures of consumption: An ethnography of the new bikers. Journal of Consumer Research, 22(1), 43-61.

Singh, T., \& Cullinane, J. (2010). Social networks and marketing: Potential and pitfalls. International Journal of Electronic Marketing and Retailing, 3(3), 202-220.

Van Doorn J, Lemon Katherin, N., Mittal, V., Nass S, Pick, D, Pirner, P, \& Verhoef, P.C. (2010). Customer engagement behavior: Theoretical foundations and research directions. Journal of Service Research, 13(3), 253-266.

Verhoef, P.C., Reinartz, W.J., \& Krafft, M. (2010). Customer Engagement as a New Perspective in Customer Management, Journal of Service Research (13), 247.

Vivek, S. D. (2009). A Scale of consumer engagement.Doctorate Thesis, The University of Alabama.

Vivek, S. D., Sharon E. B., \& Mogan, M.R. (2012). Customer engagement: exploring customer relationships beyond purchase. Journal of Marketing Theory and Practice, 20 (2), 127-149.

Wirtz, B.W., Piehler, R., \& Ullrich, S. (2013). Determinants of social media website attractiveness. Journal of Electronic Commerce Research, 14(1),11-33.

Wirtz, J., Anouk den A., Josée B., Csilla H., B. Ramaseshan, Joris van de K., Zeynep G.C., \& Jay K. (2013). Managing Brands and customer engagement in online brand communities. Journal of Service Management, 24(3),223-244.

Xevelonakis, E. (2012). The impact of social network-based segmentation on customer loyalty in the telecommunication industry. Database Marketing and Customer Strategy Management, 19(2),98-106. 


\section{Appendix}

\section{Factor Analysis for All Variables}

\begin{tabular}{|c|c|c|c|c|c|c|c|c|c|}
\hline \multirow[t]{2}{*}{ Items } & \multirow[b]{2}{*}{ Mean } & \multirow[b]{2}{*}{ SD } & \multicolumn{7}{|c|}{ Component } \\
\hline & & & 1 & 2 & 3 & 4 & 5 & 6 & 7 \\
\hline \multicolumn{10}{|c|}{ Factor 1: Cognitive Consumer Engagement } \\
\hline CE_Cognitive_24 & 2.93 & 1.19 & .860 & & & & & & \\
\hline CE_Cognitive_23 & 2.97 & 1.17 & .824 & & & & & & \\
\hline CE_Cognitive_25 & 3.00 & 1.19 & .788 & & & & & & \\
\hline CE_Cognitive_22 & 2.96 & 1.18 & .786 & & & & & & \\
\hline CE_Cognitive_21 & 2.88 & 1.20 & .771 & & & & & & \\
\hline CE_Cognitive_20 & 3.17 & 1.08 & .633 & & & & & & \\
\hline \multicolumn{10}{|c|}{ Factor 2: Brand Loyalty } \\
\hline Brand Loyalty_27 & 3.66 & 0.86 & & .821 & & & & & \\
\hline Brand Loyalty_26 & 3.62 & 0.86 & & .808 & & & & & \\
\hline Brand Loyalty_29 & 3.43 & 1.03 & & .748 & & & & & \\
\hline Brand Loyalty_28 & 3.55 & 0.98 & & .738 & & & & & \\
\hline Brand Loyalty_31 & 3.59 & 1.10 & & .724 & & & & & \\
\hline Brand Loyalty_30 & 3.29 & 1.12 & & .624 & & & & & \\
\hline \multicolumn{10}{|c|}{ Factor 3: Behavioral Consumer Engagement } \\
\hline CE_Behavioral_10 & 2.56 & 1.21 & & & .774 & & & & \\
\hline CE_Behavioral_9 & 2.39 & 1.28 & & & .736 & & & & \\
\hline CE_Behavioral_11 & 2.35 & 1.29 & & & .707 & & & & \\
\hline CE_Behavioral_8 & 3.05 & 1.09 & & & .627 & & & & \\
\hline CE_Behavioral_5 & 3.44 & 0.88 & & & .620 & & & & \\
\hline CE_Behavioral_7 & 3.39 & 0.90 & & & .590 & . & & & \\
\hline \multicolumn{10}{|l|}{ Factor 4: Trust } \\
\hline Trust_46 & 3.93 & 0.85 & & & & .838 & & & \\
\hline Trust_44 & 3.83 & 0.90 & & & & .834 & & & \\
\hline Trust_45 & 3.82 & 0.92 & & & & .831 & & & \\
\hline Trust_43 & 3.90 & 0.87 & & & & .784 & & & \\
\hline \multicolumn{10}{|c|}{ Factor 5: Emotional Consumer Engagement } \\
\hline CE_Emotional_16 & 3.64 & 0.88 & & & & & .737 & & \\
\hline CE_Emotional_18 & 3.57 & 0.91 & & & & & .718 & & \\
\hline CE_Emotional_14 & 3.64 & 0.86 & & & & & .688 & & \\
\hline CE_Emotional_15 & 3.33 & 1.17 & & & & & .600 & & \\
\hline CE_Emotional_17 & 3.31 & 1.04 & & & & & .585 & & \\
\hline \multicolumn{10}{|c|}{ Factor 6: Commitment } \\
\hline Commitment_41 & 2.97 & 1.25 & & & & & & .786 & \\
\hline Commitment_42 & 3.05 & 1.24 & & & & & & .785 & \\
\hline Commitment_40 & 3.05 & 1.21 & & & & & & .751 & \\
\hline \multicolumn{10}{|l|}{ Factor 7: Satisfaction } \\
\hline Satisfaction_33 & 3.67 & 0.85 & & & & & & & .791 \\
\hline Satisfaction_32 & 3.69 & 0.83 & & & & & & & .752 \\
\hline Satisfaction_34 & 3.81 & 0.85 & & & & & & & .739 \\
\hline & & & & & & & & & \\
\hline Eigenvalue & & & 12.500 & 3.972 & 2.065 & 1.853 & 1.538 & 1.185 & 1.029 \\
\hline Variance Explained & & & 37.878 & 12.036 & 6.257 & 5.614 & 4.659 & 3.590 & 3.118 \\
\hline Cronbach's alpha & & & .930 & .890 & .866 & .940 & .810 & .928 & .895 \\
\hline KMO Test & \multicolumn{9}{|c|}{.926} \\
\hline Bartlett Test & \multicolumn{9}{|c|}{$\chi 2=10015.983$, df: 528 Sig.: 0,000} \\
\hline
\end{tabular}

Extraction Method: Principal Component Analysis

Rotation Method: Varimax with Kaiser Normalization 
This Page Intentionally Left Blank 